\title{
The Role of the Traditional Components in Latin American Modernisation Projects (the Case of Mexico)
}

\author{
Olga Bondar ${ }^{1, *}$
}

\begin{abstract}
${ }^{1}$ Department of Social Philosophy, Faculty of Humanities and Social Sciences, Peoples' Friendship University of Russia (RUDN University), 6 Miklukho-Maklaya St, Moscow, 117198, Russian Federation *Corresponding author.Email: bondar_oyu@rudn.university
\end{abstract}

\begin{abstract}
The article reveals the peculiarity of non-Western ways of joining the process of modernisation. On an example of Latin America, the author raises the question of the external/forced character of the modernisation processes, causing deficient and unbalanced forms of their implementation. The researcher shows that the choice of strategies for joining Modernity depends on the specific historical and socio-political situation in the region. The significance of the traditional component is stated. Unlike the European development model, for which the Traditional/Historical Past was a countertrend to Modernity, in Latin America, it is presented as a necessary pillar for the latter.
\end{abstract}

\section{Keywords: Mexican Revolution, modernisation, tradition, populism}

\section{INTRODUCTION}

In the 20th century, the social and political situation became the definition of the spiritual and intellectual climate of Latin America. The global economic crisis of 1929-1933 had an impact on the industrialization of most Latin American countries. Modernisation processes that plunged Latin America into its sinkhole posed the need to self-identify in the new circumstances. The region's peripherality and dependence on the center of the world system (Europe and North Atlantic countries), technological and economic backwardness and weaknesses, historically conditioned marginalization of cultural and political spheres, set initially scarce and uneven forms of transition to modern society.

Unlike the European version of modernisation with its inherent synchronicity of occurring changes, total penetration into all spheres of social life, and its institutional character, the Latin American variant was determined by gravitation towards the traditional development vector. This largely prevented the effective course of modernisation and gave them broken forms as well as diffused, fragmented, scattered traits.

The endogeneity of modernisation processes in Europe, occurring at the level of culture (M. Weber), led to the separation of science into an autonomous sphere. Having received a sovereign status, science has avoided dependence on political sentiments, allowing development based on the internal logic of its

*Fund: The publication has been prepared with the support of the RUDN University Program 5-100. paradigms. As far as politics is concerned, it has been the subject of special consideration by several disciplines, and its influence has not gone beyond the private level of the political preferences of the agents of scientific knowledge.

In Latin America, the exogenous nature of modernisation disrupted the process of functional differentiation of spheres (N. Luhmann). In contrast to the European version with its encapsulation and isolation of functional areas, Latin America emerged in a situation of interdependence and interpenetration of the latter. The resulting context-relationships (A. Carpentier) [1], [2], contributed, on the one hand, to the free penetration and influence of the political sphere on the spiritual and intellectual life of the continent, and on the other hand, to the active participation of the intellectuals in politics.

\section{POPULISM: A LATIN AMERICAN RESPONSE TO THE CHALLENGE OF MODERNISATION}

Latin America's transition from Tradition to Modernity, reduced to the implementation of exemplary European models of development, was complicated by the threat of an abnormal state due to the lack of cultural and historical potentials, provided the time was short. The Latin American response to the said challenge was populism. It held back the possibility of discarding the progress and served as a safety belt. The role of populism on the continent prompted local intellectuals to call it a genuinely Latin American creation. The fact that in other geographical latitudes populism was not represented so widely gives 
researchers of the phenomenon grounds to speak about its Latin American version [3].

As for the notion of populism, for all its intuitive clarity, it seems quite a task to elaborate a formal definition. Contextual dependence on political, economic, sociological (socio-)psychological, philosophical rites gives its borders fluidity, thus expanding its content. In a wide range of its variant cases, the following definitions are the most representative: the form of "political structuring" / "discursive practice with its inherent stylistic specificity" (E. Laclau, C. Mouffe); "historical phase in the modernisation of the economic structure of a state" (O. Ianni); "form of socio-political mobilization, where charismatic leaders manipulate the masses" (G. Germani) [4], [5], [6].

Meanwhile, it seems possible to articulate the context-independent "dense core" of the phenomenon of populism and, having revealed its explanatory potential, to represent it in the form of a designation, categorizing its co-sustainability. An analysis of the various studies on the subject reveals the following composition:

- An attitude of holism and the historical justification of collective subjectivity.

- The substitution of the notion of the popular type of collective identity with the national identity.

- Authoritarian reflex syndrome - the paradigm of political behavior (of the subjects), defined by an irrational belief in a charismatic personality (leader).

- The etatist-paternalistic form of the social structure affirms the leading role of the state in the political and social life of society, as well as the father-son relationship between the authorities and citizens.

- Patron-client relations as a way of social and political integration.

The impact of this social and political phenomenon found on the continent cannon be overemphasized. According to Latin American sociologist F. Calderón, populism has become a tool of joining and connecting the continent to the universal and paradoxical experience of modernisation, assigning modernisation with Latin American features [7].

The ideological platform of Latin American populism was the 19th-century civilizing project adapted to modern conditions. Unlike its developers liberals and positivists of the 1837 Generation (J. B. Alberdi, D. F. Sarmiento, and others), who saw the goal of creating a true/pure nation, capable of assimilating the achievements of progressive countries - the conductors of the populist project of the 20th century were distinguished by the desire to awaken a strong sense of spiritual unity in Latin American nations; in it, they saw a solid foundation that could ensure the implementation of modernisation. The economic basis was a policy of import substitution and protectionism in the form of support for the domestic market, its protection from foreign competition and capital. The kay actor in the continent's modernisation processes was the national bourgeoisie. By acquiring control over the economic and political spheres, this agent of the domestic market set the course of the continent's development towards modernity.

Latin America's entry into the band of radical changes took place against the background of its social diffusion. This situation required the intellectual elites to bring everything national to every level of social practice - production, politics, economics, art, literature, philosophy, and so on - whose standardization and rationalization would make it possible to talk about their ethnic roots. As for populism, the degree of its impact on the culturalhistorical situation and the spiritual atmosphere helps to expose the events that took place in Mexico, and that became significant for the entire continent during the first third part of the 20th century.

\section{MEXICO: THE QUEST FOR AN ENTRY INTO MODERNITY}

Scrutinizing the events, that shaped the first populistic regime in the chain of such in Latin America, and using the Mexican revolution of 1910-1917 as a vivid example, a researcher can assume that the ideological roots of the phenomenon of revolution go back to the process of modernisation that involved European institutions and social norms [8], [9], [10]. European modernisation, reduced to the process of social rationalization, marked a transition to modern society, established by the force of reason. Obsessed with the motto Let's make a clean slate out of the past, the rationalistic way of development renounced the historical past as a means of support, displacing the traditional, irrational component from the social life. This renunciation is a revolution - the victorious act of transition from irrationality to reason, an act committed in the name of domination and triumph of reason.

The European type of modernisation creates the semantic field of the notion of revolution, and, by conjugating it with the idea of development, removes its negative connotations. In the transition to modernity, stability supplants instability, serenity takes the place of confusion, order replaces chaos, and universality comes after particularity. In turn, the shifts in the economic, political, cultural, and social spheres begotten by revolutionary transformations are seen as "mutations 
and triumph of reason, comprehended (...) as a kind of force of nature" [11].

Having adopted a peripheral form on Latin American soil, modernisation processes, complicated and burdened by its marginalization, resemantize (European) notion of revolution. The triggers for these processes in Mexico were its dependence on foreign capital, actively supported by the president Porfirio Díaz, and his promotion of the interests of the oligarchs. The further motivation for the struggle for economic freedom was complemented by ideological opposition to positivism, adopted by P. Díaz as the official ideological basis of his political course. Activists of a new type - a generation of academics (científicos), representatives of the wave of the Mexican positivism, personifying ruling elites transformed it into the tool of state management. With the help of "scientific" methods, they strengthened the monopoly of foreign entrepreneurs in all spheres of the economy and increased the exploitative relations within the country [12]. The Porfiriato clique didn't express genuine (in Comte's meaning) positive political and social ideals but "used the ideas of positivism, putting them at the service of completely alien interests" [13].

The socio-political context in Mexico, influenced by positivism as a "philosophical system that justifies the new orders," describes the state common for the whole continent. Leopoldo Zea, who explored the emergence and role of positivism in Latin America, notes that in the name of a new order, based on the idea of reason and progress, "political freedoms were sacrificed (...). The only freedom is now considered to be the freedom of enrichment and material domination of those stronger, as taught by the new philosophical concepts" [14].

Critical mass increased from external and internal calls. Having reached its peak, it made the revolutionary explosion inevitable: i.e., the rejection of implanted Modernity, identified with the imposed forms of capitalism and positivism, that had turned the country into a subsidiary of the Western civilization. The mechanism of inversion — the historically instantaneous recoil to the opposition of modernity to the Tradition - set the dynamics of revolutionary processes. The movement, countering the European modernisation, determined the awakening of the national consciousness in the aspirations of Mexicans to grasp who they are, what is their place in history.

Mexico sees sharp growth in the interest in the traditions of national culture and art. Artistic activities and creative writing turn to the origins. Revolution, providing novels and poems with additional genre texture, is accompanied by a search for the roots in the fine arts. Graphic artists and painters, embodying the revolutionary theme, are reviving the traditions of indigenous peoples of the Americas, unearthing, in the words of A. Reyes, a "forgotten heritage (...), a golden treasure, hidden by the Aztecs, according to the legends" [15]. In this appeal, the indigenous roots are perceived as an inexhaustible source of national forces and energies, setting in motion and interaction all forms of ideological and artistic life of a state. As a cultural substrate, it added to the "golden stock" of world culture of those years, entering it as the brightest phenomenon known as the Mexican Renaissance. Trends, marked by a sympathetic interest in indigenous history and culture, have eventually developed into a sustainable tradition of Indigenismo, which, since the 1920 s, turns into the core of official ideology and remains in this status despite the volatility of political orientations and passions.

The issue of national integration, exacerbated by historical circumstances, transformed Indigenismo from a literary and artistic to a practical dimension, turning it from a set of ideas into a program ready for realization. The solution was seen in the enlightenment of the natives, in its transformation into a dynamic component of social life through connection to the currents of the emerging modern civilization. M. Gamio reflects on the "indigenous topic" in his work with the symbolic title "Strengthening the Motherland (Pro Nationalism)" [16]. The anthropologist saw the policy in the field of education that consults regional peculiarities of cultures, and that considers them when elaborating educational projects. The latter are coordinated in such a way that they form a single national system. Prominent Mexican philosopher J. Vasconcelos, then the Secretary of Public Education, criticized Gamio's program. J. Vasconselos sensed a threat of reinforced detachment and isolation of the autochthonous population. They, therefore, advocated the introduction of a united national (school) education system that could become a powerful tool of integration. Similarly, in 1924 the issue of national integration was a strong argument for adopting a bilingual model for the education system.

Indeginismo enters the cultural-philosophical reflection, settling in a few sustainable themes and issues, namely: a critique of the European cultural traditions; an appeal to autochthonous values; an idea of exclusivity; a problem of the idiosyncrasy of the Mexican people; creation of a psychological portrait of an Indometis Mexican; the quest for a "new humanism"; the theme of messianism. Thus, the national values, buried in oblivion by the Porfiriato dictatorship with its obsession over Europe and cosmopolitan leanings, regained their existential fullness only due to the profound social upheaval experienced by the country.

The Mexican Revolution resonated with the public in Latina America and beyond. Attempts of various representatives of intelligentsia, its contemporaries, and 
the post-revolutionary generation to define the events received several formulations: for a Mexican O. Paz, it was the "immersion of Mexico into its essence," for a French J. Franco it was "return to roots." A Dominican P. H. Ureña, emphasizing the Revolution's continental importance, defined it as a "step towards expressing the true spirit of America." Despite the semantic shades of the language used, these definitions shared one profound idea: "the Revolution was like an internal explosion of historical reality," turning Mexico to itself. What occurred was "more than a revolution - it was a discovery" [17]

Disclosing the impact of the Revolution on the country's spiritual life, O. Paz resorts to the concept of tradition. Rejecting well-established definitions, he offers his interpretation: it is the "program of a general idea, through which a nation finds its place in the modern world." He considers the quest for tradition, able to rework "national limitations," to be the driving force of a revolution. In this context, the Mexican Revolution carries a double semantic load: it is both a return to the roots and an attempt to fit into a common tradition (Modernity) - i.e., a way to overcome the "historical lag" [18].

O. Paz's comprehension of the Revolution seems to significantly clarify and reveal the peculiarity of the inversion mechanism that forms it, which a researcher may compare with the movement of a pendulum of history. In it, the reverse flow is also made when moving from one pole of history to the opposite. Yet the transition to Modernity doesn't mean a rejection of the historical past, but, on the contrary, it's "holding," "grasp." For Paz, the country's modernity is embedded in its historical past, otherwise, without this reliance, it faces extinction, "since sooner or later any era ceases to be modern, we risk being left without our own name" [19].

\section{CONCLUSION}

By the first quarter of the 20th century, under objective circumstances, for the Mesoamerican region, the transition to a new phase of historical development - Modernity - had at its core the form of forced transplantation of models and samples set by European culture. However, the impossibility of their unambiguous acceptance given the historical distance between the progressive center of the world system and peripheral grounds was a factor of the compulsive search and justification of own/authentic ways of Mexico's development. The breakthrough to the genuine existence, to the Mexican reality free of European borrowings and imitations, was the radical social and political transformation that unveiled the historical layer from the depths to the surface. The decisive point in addressing the historical path was not the immersion into it, which in its extreme version could take another "form of Bovarysme - the escape from the present" [20] but the strive to derive from it an interpretation of culture that, given the culturalhistorical situation in Mexico, would serve as an impulse for independent development and, becoming the touchstone for action in the present, would determine its future. The condition set a guiding vector for cultural-philosophical reflection that turns into the philosophy of the "Mexican Essence."

\section{References}

[1] V. Kuteyshchikova, Preface to the book "Writers of Latin America on Literature", Writers of Latin America on Literature, M., 1982, p. 10.

[2] A. Carpentier, Problematics of Modern Latin American Novel, Writers of Latin America on Literature, M., 1982, pp. 35-37, 39.

[3] O. Gonzales, Los orígenes del populismo latinoamericano. Una mirada diferente, Cuadernos del Cendes, Año 24, n.6, Tercera época, Sept.-dic.

[4] N. Yakovleva, This Sweet and Scary Word Populism, Latin America, 2011, n. 10

[5] T. Rusakova, Venezuela: Radical Populism and the Formation of the Political Course of H. Chávez. Thesis for PhD in Political Science, Moscow, 2010.

[6] E. Dussel, Cinco tesis sobre el populismo, El eterno retorno del populismo en América Latina y el Cáribe, Bogotá, 2012.

[7] F. Calderón, América Latina: Identidad y tiempos mixtos - O como tratar de pensar la modernidad sin dejar de ser indios, Cultura, estética y política en América Latina, Caracas, 1994.

[8] B. Kapustin, About the Subject and Use of the Concept of "Revolution", Logos, 2008, n. 6.

[9] M. Malia, Locomotives of History: Revolutions and the Establishment of the Modern World, M., 2015.

[10] A. Touraine, The Idea of Revolution, Sociological Review, 2014, 13 (n.1).

[11] A. Touraine, The Idea of Revolution, p. 99.

[12] M., Alperovich, L. Slezkine, History of Latin America, M., 1981, p. 264

[13] L. Zea, El Positivismo en México, México, 2005, p. 236

[14] L. Zea, From Romanticism to Positivism in Latin America, Journal of World Culture History, 1960, n. 3, p. 23.

[15] V. Kuteyshchikova, About Some Features of Mexican Prose, Artistic Peculiarity of Latin American Literature, M., 1976, p. 211.

[16] M. Gamio, Forjando patria. (Pro nacionalismo), México, 1916.

[17] O. Paz, Selected Works, M., 2001, p. 21.

[18] O. Paz, pp. 130, 132.

[19] O. Paz, p. 145

[20] L. Zea, Philosophy of American History. The Historical Fates of Latin America, M., Progress, 1986, p. 36. 